\title{
Development of interactive tutorial video based on curriculum based on Indonesian national qualification framework in machinery material Basic completion of completion
}

\author{
Muslim $^{1 *}$, Selamat Riadi ${ }^{1}$, Nur Basuki ${ }^{1}$ \\ \{*muslim@unimed.ac.id \} \\ ${ }^{1}$ Universitas Negeri Medan
}

\begin{abstract}
This development research aims to develop a curriculum-based interactive video tutorial based on the Indonesiannational qualification framework in the basic turning competency machining course at the Mechanical Engineering Education Study Program. Curriculum-based interactive video tutorial based on the Indonesian national qualification framework at the engineering course This basic turning competency is designed to be able to improve student learning outcomes so that they can fully understand the material provided in the engineering course. This study uses the development method of the IDI (Instructional Development Institute), as for the procedure for developing the IDI, namely: define, develop, and evaluate. Type of data is primary data where data is provided by media experts, lecturers and students. The data analysis technique used is descriptive data analysis technique that is by describing validity, practicality and effectiveness using a curriculum-based interactive video tutorial based on the Indonesian national qualification framework in the basic turning competency machining course. The results obtained from this research and development are as follows; a Material expert: (1) Quality of learning material with a validation value of 0.90 ; (2) Quality of Learning Strategies with a validation value of 1.10; (3) About the learning delivery system with a validation value of 0.88 . So that it can be seen the trend level of the assessment of material experts in a score of 0.96 with a range of "Valid"; $b$. Learning design experts: (1) Quality of learning design with a validation value of 0.94 ; (2) Quality of Learning Strategies with a validation value of 0.91; (3) About aspects of the quality of the interaction design with a validation value of 0.91 (4) Regarding the aspect of presentation quality with a validation value of 0.89 ; c. Media Experts: (1) Programming Aspects with validation values of 0.92 ; (2) Graphic design aspects on technical or display quality with a validation value of 0.94 ; (3) Technical Quality Aspects or performance with a validation value of 0.91 ; So that it can be seen the level of tendency of experts or material expert validators, learning design experts and meida experts in the average score of 0.91 in the "Valid" category. Practical test results of curriculum-based interactive video tutorials based on the Indonesian national qualification framework in machining courses Basic turning competencies by lecturers and students are conducted through lecturer and student response questionnaires showing the results of practical test curriculum-based interactive video tutorials based on the Indonesian national qualification framework in machining courses Basic turning competency courses by the response of the lecturer to show the level of practicality with the percentage of $88.75 \%$ in the practical category. practicality test the curriculum-based interactive video tutorial based on the Indonesian national qualification framework at the machining course the basic turning competency by the student response shows the practicality level with the percentage of $98.2 \%$ in the very practical category. A curriculum-based interactive video tutorial based on the Indonesian national qualification
\end{abstract}




\begin{abstract}
framework in the machining course Practical basic turning competencies means facilitating students. Effectiveness test results of curriculum-based interactive video tutorials based on the Indonesian national qualification framework in machining courses Basic turning competencies are effective in improving student learning outcomes before using after Animation-Based Multi Media. The increase in student learning outcomes was marked by an increase in the number of 59 students who passed as many as 55 people, $93.22 \%$. Based on the findings of this study, it was concluded that a curriculumbased interactive video tutorial based on the Indonesian national qualification framework in machining courses Effective basic turning competencies is valid, practical, and effective to be used as a learning media in basic network training eyes.
\end{abstract}

Keywords: Development of Management Models, Expertise Competencies, Production Units, Vocational Schools.

\title{
1 Introduction
}

Education is a planned effort to realize the learning atmosphere and the learning process so that students effectively develop their potential to have spiritual strength, personality and skills possessed by themselves, the people of the nation and the state. Educational success depends on changing attitudes or achieving the final results of learning. Based on the government regulation of the Republic of Indonesia Number 31 of 2013 concerning National Education Standards, Article 19 paragraph 1 states that: The educational process in educational units is held in an interactive, inspirational, fun, challenging, motivating student to actively participate and provide sufficient space for initiatives , creativity, and independence in accordance with the talents, interests, and physical and psychological development of students (Government Regulation, 2013).

The Indonesian National Qualifications Framework (KKNI) curriculum will improve the quality of university graduates, that in the IQF curriculum contains subject competencies consisting of cognitive, psychomotor, and affective or attitude. So far there are still many courses that only use cognitive elements (Hendrawan, 2012: 1). Machining learning is a practical learning that is tied to skills in working on an object with the help of a machine. In machining learning will get lessons about turning. Turning is a process for forming objects by means of feeding by cutting or reducing the dimensions of the workpiece (Daryanto, 1996: 1). Basic turning is the first practice course that works using a lathe. In basic turning learning students will get material about straight, groove, taper and outer thread turning.

Learning media is a tool in the learning process both inside and outside the classroom, so media selection requires many considerations, including the feasibility of the media used [1]. Interactive multimedia provides more value to learners to be actively involved in the learning process, thus providing a deeper learning experience. In addition, the use of multimedia in learning is suitable for various learning styles because it prioritizes various aspects, such as audio and visual aspects simultaneously. To form effective, interesting and not boring learning for students, it is necessary to develop learning media that are in accordance with the conditions and characteristics of students. Learning curriculum-based interactive video tutorials based on the Indonesian national qualification framework is learning that uses media in the form of moving images, so learning will be more meaningful and effective. According to [2]learning video media is a media that presents audio and visual which contains good learning messages that contain concepts, principles, procedures, application theories to help 
understanding a good learning material. Learning that means having meaning as an in-depth understanding of the material, includes paying attention to important aspects of the material presented by educators, organizing it mentally into a cognitive structure.

The basic machining practice is the first practical course that deals with real machines, so in this practice students are stressed to have the skills and knowledge about the procedures for turning with a real machine. In terms of practice, educators have important things, namely educators who regulate the teaching and learning process. The success of the learning process is very dependent on the delivery of material provided by the educator. The problem in delivering basic machining material is the loss of the lecturers' voice due to the noise of the workshop area. Apart from these problems, other problems that occur in learning that educators must demonstrate how to turn procedures. Demonstration of the turning is less efficient because a lot of time is taken and students must cluster in one machine. The time is long because the material delivered is very long and the procedures that are applied are very large, in addition to this the hordes of students make the sound of educators unable to be heard clearly because of the noise of the process of shooting and irregular learners.

As a result of this learning, many students are not able to get good information, so that the information available to students is difficult to imply. Many students take basic machining courses but the practice of turning is done by a classmate. Therefore, researchers will help provide information to students by developing the development of curriculum-based interactive video tutorials based on the Indonesian national qualification framework in the basic turning competency machining course. This media is expected to be able to be used as a learning tool for students who do not understand how to operate a lathe and do turning.

\section{Methodology}

The development model used is the Instructional Development Institute (IDI) model. According to (Gustafson \& Brach, 1997, IDI applies the principles of a system approach that includes the stages, namely discovery (define) or needs analysis, development (develop), and evaluation (evaluate). The first stage is the discovery stage (define) which contains steps of background analysis and problem identification The second stage is the development stage which contains the preparation of the initial form (product prototype) and product validation, while the third step is the evaluation / evaluation stage which contains the test steps and analysis of trial results.

The product trial was conducted to find out the practicality and effectiveness of the interactive video tutorial on the engineering course. The trial was carried out in the Faculty of Engineering, Department of Mechanical Engineering Education, State University Academic Year 2018/2019.

The subject of the trial was an educational student with a UNIMED FT machine who was given learning using a curriculum-based interactive video tutorial based on the Indonesian national qualification framework in the basic turning competency machining course. Subjects for testing the development of curriculum-based interactive video tutorials based on the Indonesian national qualification framework at the engineering course Basic turning competencies are students of the Mechanical Engineering Education Department, Medan State University, in machining courses in the Odd Semester academic year 20018/2019. 


\section{a. Data Collection Instrument}

The instruments developed to collect data in this study are as follows: (1) Validation sheet; (2) Practical Sheet; (3) Effectiveness Sheet; (4) Data Analysis Techniques. Data from curriculum-based interactive video tutorial validation based on the Indonesian national qualification framework in machining subjects Basic turning competencies in the form of content validation, presentation validation, and format validation were analyzed using the following steps:

Syaifuddin Azwar (112-112: 2013), one of the statistics that shows the validity of item content is as proposed by Aiken (1985). Aiken has formulated the Aiken V formula to calculate the content-validity coefficient based on the results of the expert panel's assessment of $n$ people on an item in terms of the extent to which the item represents the measured construct. In this case representing the measured construct means the item in question is relevant to the behavior indicator, because behavioral indicators are operational translations of measured atribbut. The judge is done by giving a number between 1 (i.e. the expression is not representative or very irrelevant) up to 5 (i.e. very representative or very relevant).

Table1. Research design

\begin{tabular}{|c|c|}
\hline \multicolumn{2}{|c|}{$\begin{array}{l}\text { Interactive learning media with the Edmodo application In Engineering Drawing } \\
\text { Course }\end{array}$} \\
\hline $\begin{array}{l}\text { Use curriculum-based interactive video } \\
\text { tutorials based on the Indonesian } \\
\text { national qualification framework in the } \\
\text { basic turning competency machining } \\
\text { course }\end{array}$ & $\begin{array}{l}\text { Use curriculum-based interactive video } \\
\text { tutorials based on the Indonesian } \\
\text { national qualification framework in the } \\
\text { basic turning competency machining } \\
\text { course }\end{array}$ \\
\hline
\end{tabular}

\section{Result and Discussion}

\subsection{Expert Validation Results}

Determination of validity data for curriculum-based interactive video tutorials based on the Indonesian national qualification framework in machining subjects Basic turning competencies as learning media are using questionnaires. In this case the researcher gave a questionnaire to six validators who validated the media being developed, namely: (1) Three validators were called the first material experts to carry out validation and assessment of the content (material), (2) Three validators called Learning design experts, (3) Three The validator is called the Learning media expert.

In this development research produces a learning media that is multi-media based animation that is stated to be very valid and the basic turning tutorial video has fulfilled several aspects with validity values namely:

Table 2. Expert Validation Result

\begin{tabular}{clcc}
\hline No & \multicolumn{1}{c}{ Expert } & $\%$ & Information \\
\hline 1 & Material Expert & 0,96 & Valid \\
2 & Learning Design Expert & 0,73 & Valid \\
3 & Media Expert & 0,87 & Valid \\
\hline
\end{tabular}


From the table above can be explained as follows, a. Material experts: (1) Quality of learning material with a validation value of 0.909 ; (2) Quality of Learning Strategies with a validation value of 1.10; (3) About the learning delivery system with a validation value of 0.88 . So that it can be seen the trend level of the assessment of material experts in a score of 0.96 with a range of "Valid"; b. Learning design experts: (1) Quality of learning design with a validation value of 0.94 ; (2) Quality of Learning Strategies with a validation value of 0.91 ; (3) About aspects of the quality of interaction design with a validation value of 0.90 (4) About aspects of presentation quality with a validation value of 0.73 ; c. Media Experts: (1) Programming Aspects with validation values of 0.92 ; (2) Graphic design aspects on technical or display quality with a validation value of 0.94; (3) Technical Quality Aspects or performance with a validation value of 0.93 ; So that it can be seen the trend level of experts or material expert validators, learning design experts and meida experts in the average score of 0.87 in the "Valid" category.

\subsection{Practicality Test Results}

The results of the practical test of basic turning tutorial videos by lecturers and students were carried out through teacher and student response questionnaires indicating the results of the practical test of basic turning tutorial videos by lecturer responses showed a level of practicality with $88.75 \%$ in the practical category. the practical test of the basic turning tutorial video by the lecturers' response showed a level of practicality with a percentage of $98.2 \%$ in the very practical category. The practical basic turning video tutorial means making it easier for students to understand basic turning learning. Rudi Susilana and Cepi Riyana, (2007: 03) revealed that the good and bad of learning is supported by users of learning media. The basic turning tutorial video is able to make the learning atmosphere pleasant, because students are more motivated to complete learning.

\subsection{Effectiveness Test}

Learning outcomes data was taken aiming to see the extent of student achievement in participating in the learning process by using a curriculum-based interactive tutorial video score based on the Indonesian national qualification framework in the basic turning competency machining course. Data on learning outcomes were taken after $4 \mathrm{x}$ meetings in learning, with 30 multiple choice questions. From the data obtained 55 students who have completed $(93.22 \%)$ of the 59 students and students who have not finished are as many as 4 people $(6.78 \%)$, an increase of 18 graduates or 60.00

\section{Conclusion}

From the results and discussion of research on the development of curriculum-based interactive video tutorials based on the Indonesian national qualification framework in the basic turning competency machining course stated earlier, it can be summarized as follows:

The video tutorial product specifications developed by researchers can be explained as follows: (a) This media base turning tutorial video was developed using camtasia 8 software. And flash 8. (b) This media is a learning media for basic turning tutorial videos that are operated independently. (d) The tutorial video material is basic turning. (e) this video tutorial contains the basic turning learning component. (f) Minimum computer requirements for 
running multi-media based on this animation: pentium II procecor $500 \mathrm{Mhz}, 64 \mathrm{MB}$ RAM, 48X CD ROM, Windows 98 Operating System 800x600 resolution and speaker.

The form and content of the basic turning tutorial videos are in the form of CDs (Compact Disks) that contain files with the extension "exe" on the composition of the basic turning material, the availability of tutorial videos on video pages, musical instruments on the home page, and images on each engineering subject matter audio system.

In this development research produces a learning media that is multi-media based animation that is stated to be very valid and the basic turning tutorial video has fulfilled several aspects with validity values, namely: a. Material experts: (1) Quality of learning material with a validation value of 0.909 ; (2) Quality of Learning Strategies with a validation value of 1.10; (3) About the learning delivery system with a validation value of 0.88 . So that it can be seen the trend level of the assessment of material experts in a score of 0.96 with a range of "Valid"; b. Learning design experts: (1) Quality of learning design with a validation value of 0.94; (2) Quality of Learning Strategies with a validation value of 0.91; (3) About aspects of the quality of interaction design with a validation value of 0.90 (4) About aspects of presentation quality with a validation value of 0.73 ; c. Media Experts: (1) Programming Aspects with validation values of 0.92 ; (2) Graphic design aspects on technical or display quality with a validation value of 0.94 ; (3) Technical Quality Aspects or performance with a validation value of 0.93; So that it can be seen the trend level of experts or material expert validators, learning design experts and meida experts in the average score of 0.87 in the "Valid" category. Where according to Trianto (2010: 269) Valid means that it has provided accurate information about teaching materials developed.

The results of the practical test of basic turning tutorial videos by lecturers and students were carried out through teacher and student response questionnaires indicating the results of the practical test of basic turning tutorial videos by lecturer responses showed a level of practicality with $88.75 \%$ in the practical category. the practical test of the basic turning tutorial video by the lecturers' response showed a level of practicality with a percentage of $98.2 \%$ in the very practical category. The practical basic turning video tutorial means making it easier for students to understand basic turning learning. Rudi Susilana and Cepi Riyana, (2007: 03) revealed that the good and bad of learning is supported by users of learning media. The basic turning tutorial video is able to make the learning atmosphere pleasant, because students are more motivated to complete learning.

Effectiveness Test Results. Data on learning outcomes were taken after $4 \mathrm{x}$ meetings in learning, with 30 multiple choice questions. From the data obtained 55 students who have completed $(93.22 \%)$ of the 59 students and students who have not finished are as many as 4 people $(6.78 \%)$, an increase of 18 people graduated or $60.00 \%$.

\section{References}

[1] A. Arsyad, Media Pembelajaran. Jakarta: PT. Raja Grafindo Persada, 2006.

[2] C. Riyana, Pedoman Pengembangan Media Video. Jakarta: P3AI UPI, 2007. 